\title{
Lake Parramatta
}

\section{Matti Keentok}

Lake Parramatta is about two kilometres north of Parramatta's central business district, on Hunts Creek. The reserve in which Lake Parramatta lies has gone through significant changes in its short history of European settlement. Originally a place of Aboriginal habitation by the Burramattagal clan, it has since seen occupation by people engaging in illicit production of spirits ${ }^{1}$ and by bushrangers (as was the case for neighbouring Darling Mills Creek); a short period of farming; a water reservoir supplying drinking water for Parramatta; and subsequently a place of recreation including swimming. These and other uses have left a number of relics still visible, although not obvious.

Aboriginal heritage abounds in caves and cave paintings; however, much of this is now submerged. People on holiday walking on the shores of Lake Parramatta may not realise that the paths they are tramping are in fact heritage roads, which are often not recognised in local history. Today Lake Parramatta has many recreational uses: a picnic and barbeque spot with water views, a swimming pool (subject to water quality warnings) and a place for a bush walk along many tracks which circle the lake.

The lake is formed by a heritage dam, which has been researched by Engineers Australia, the organisation representing professional engineers and engineering officers in Australia. The dam, found in a gloomy gully, has created historical records but is the source of a mystery, which has not been solved despite recent research.

\section{Parramatta's water supply}

The original water supply for Parramatta was the Parramatta River, which was subsequently dammed during Macquarie's governorship by the construction of a weir at Marsden Street. A second dam was constructed on the river near the Female Factory, later Asylum. ${ }^{2}$ As Parramatta grew and small industry developed along the riverside, the demand for water increased and the water quality decreased due to industrial and human pollution. For some time, consideration was given to the construction of another new dam as a water supply, and sites were considered on Hunts Creek and Toongabbie Creek. ${ }^{3}$ Hunts Creek was eventually chosen by council, based on advice given by engineer Percy Simpson. John Pye owned land around Hunts Creek, which he offered for construction of the dam. Council accepted Pye's offer.

\section{The dam}

Lake Parramatta dam is a cylindrical arch dam of advanced design. Arch dams rely on good attachment points to withstand the water pressure, whereas gravity dams (such as Warragamba Dam), by contrast, rely on the dam's weight.

Who designed the dam is a mystery. Percy Simpson, a civil engineer with nautical experience in the Royal Navy, is usually attributed as the designer of the cylindrical arch dam. ${ }^{4}$ It is 
claimed that this was the second time in world history that the thin cylinder formula was used in designing an arch dam. ${ }^{5}$ Contractor W Randle constructed the dam under the supervision of engineer EO Moriarty. ${ }^{6}$ Recent research by Ash and Heinrichs ${ }^{7}$ has shown the historical evidence does not positively identify Simpson as the designer, and in fact shows that Moriarty and even Randle had some part in the design. There is historical evidence that Simpson chose the dam site, ${ }^{8}$ had contact with the designer of the Zola arch dam, ${ }^{9}$ suggested a 'circular' (arch) design ${ }^{10}$ and prepared plans for Randle (or Randall). ${ }^{11}$

The research of Ash and Heinrichs gives credibility to the usage of the cylinder formula in the design. Dam experts Chanson and James ${ }^{12}$ consider that Lake Parramatta dam was designed using the cylinder formula, which is consistent with the fact that Simpson had contact with the designer of the Zola dam, also designed according to the cylinder formula. The dam is unusually thin for its time and is still structurally sound, which is also supportive of the formula being used in the design. ${ }^{13}$

Lake Parramatta dam was the first arch dam built in Australia ${ }^{14}$ and remains an important part of Australia's engineering heritage. ${ }^{15}$ An Engineering Heritage plaque from Engineers Australia can be found across the road from the kiosk. The engineers involved in the design and construction of Lake Parramatta dam rose to prominence in their profession and were in the forefront of international engineering. ${ }^{16}$

Construction of the dam started in 1855 under the supervision of engineer EO Moriarty with the laying of the foundation stone; it was completed in $1856 .{ }^{17}$

The dam was constructed from sandstone blocks set with Roman cement. Sandstone for the dam was quarried from two locations above the dam site. The success of this dam encouraged the construction of a series of concrete thin arch dams in the Blue Mountains (and elsewhere in New South Wales), one of which is still the thinnest concrete arch dam in the world. Thin arch dams saved considerably on material and hence were low in cost, but required good attachment points.

\section{Supplying the water}

While the dam was finished by 1856, it was not used as a reticulated water supply for Parramatta until after $1881,{ }^{18}$ although in the intervening years water carts supplied drinking water to those who would pay for it. The initial hurdle was the fact that the council was not eligible to be a water authority. Once this was corrected by legislation, the council soon found itself in the position of not having sufficient finances to connect the dam to Parramatta. Over a long period of time there was interminable wangling in council. Finally $£ 6,800$ was found to construct the water supply system and lay the pipes. ${ }^{19}$ Well-known Sydney engineer Norman Selfe designed the water supply system, consisting of the pumping station, filter beds and settling tanks. ${ }^{20}$ Little visible evidence remains today of this water supply system.

In 1885, the dam ran dry. By the 1890s, Hunts Creek dam was still low and moves were made to connect to the Water Board's mains. ${ }^{21}$ In 1898 the dam wall was raised 11 feet (3.35 metres) with a concrete extension following CW Darley's design, to meet increasing demand for water. ${ }^{22}$ 
By 1909, Parramatta was connected permanently to the water supply developed by the metropolitan Water Board and the reticulation to the lake was disconnected. ${ }^{23}$ Recreational uses of the lake took over and during the 1930s the lake was a favourite swimming pool with its own surf life saving club. ${ }^{24}$

\section{The heritage roads of Lake Parramatta}

On the western side of the lake can be found a heritage road dating from 1887 when unemployed men were given relief work building it. ${ }^{25}$ The road runs from North Rocks Road to the edge of the lake, on the opposite shore from the reserve car park -the full extent of this road and the associated stone work is not generally known. On this route the road progresses from a cobbled road at North Rocks Road, to a dirt track overlooking the lake, to a cobbled track supported either side by dry-stone walls, with 'wings' extending 100 metres along the lake side. The road is about 15 feet ( 4.5 metres) wide for much of its length. At one end, the road perches high above the Lake Parramatta dam, passing two quarry sites and many backyards supported by dry-stone walls. The rest of the route is largely overgrown and is crossed by narrow walking tracks, which meander over the surface of the road and finally leave it near the lake foreshore. A portion of the heritage road near the foreshore is totally inaccessible to bushwalkers, although the dry-stone walls supporting it are visible to the keeneyed.

The two quarries that supplied the stone for the dam are perched on the hillside below the heritage road and above the dam. Other quarries, such as Pye's quarry in North Rocks, may also have supplied sandstone for construction of the dam.

There is another heritage road (Illawong Drive) on the eastern side of the lake, which is of unknown derivation and largely unrecognised. Near the Lake Circuit track is a bituminised road, now protected by a locked gate accessible only to pedestrians and cyclists. This early section of a heritage road is supported by sandstone blocks and later dry-stone walls, which are visible to walkers on the She-Oak Circuit. This portion of the road has disappeared under a coat of bitumen - but all will be revealed soon.

As the road turns to follow the lake, the bitumen disappears, exposing the original surface of cobbled stones. A large number of fragments of cobbled road, the longest about 30 metres long, can be seen along the eastern side of the lake. Short sections of sandstone edging may also be seen. Where the road crosses a creek, there is a small stone bridge, now modified by insertion of a concrete pipe and overgrown. Further on, there are two small culverts made of sandstone blocks. No archaeological study has been undertaken to my knowledge, so it is not known how old this road and its related structures are - certainly not recent due to the eroded state of the cobbling. One heritage report gives the date of construction of the road as $1857 .{ }^{26}$ Matti Keentok is a mechanical engineer at the Department of Defence with an interest in engineering heritage 


\section{Endnotes}

${ }^{1}$ Plan of Management Lake Parramatta Reserve, vol 1, Report prepared for Parramatta City Council, 1999, p 20, available at http://www.parracity.nsw.gov.au/home/publications/recreational/lake_parramatta_plan_of managem ent, viewed 25 February 2009; The Bushland of Hunts Creek Reserve, Baulkham Hills Shire Council, undated

${ }^{2}$ This is Parramatta Pioneer City of a Nation, Cumberland Press, Parramatta NSW, c1970, p 61; John McClymont, Brief Histories of Parramatta utilities and services, Course notes for Parramatta Evening College, 1998, p 2

${ }^{3}$ T Kass, C Liston, J McClymont, Parramatta: A past revealed, Parramatta City Council, 1996, p 164; J Jervis, The Cradle City of Australia A history of Parramatta, Council of City of Parramatta, 1978, p 157

${ }^{4}$ Beverley Johnson, 'Simpson, Percy (1789-1877)', Australian Dictionary of Biography, supplementary vol, Melbourne University Press, 2005, pp 362-63

${ }^{5} \mathrm{H}$ Chanson, DP James, 'Historical Development of arch dams: from cut-stone arches to modern concrete designs', Australian Civil Engineering Transactions, vol CE43, 2002, pp 39-51

${ }^{6} \mathrm{H}$ Chanson, P James, 'Rapid reservoir sedimentation of four historic thin arch dams in Australia', Journal of Performance of Constructed Facilities, vol 12, no 2, 1998, pp 85-92

${ }^{7}$ R Ash and P Heinrichs, 'Parramatta Single Arch Dam - From 1856 and still going strong', First International and Eighth Australian Engineering Heritage Conference, 29 September-2 October 1996, Newcastle, NSW

${ }^{8}$ T Kass, C Liston, J McClymont, Parramatta: A past revealed, Parramatta City Council, 1996; EJ Statham, 'Parramatta Waterworks', Journal of the Parramatta and District Historical Society, vol 2, 1921

${ }^{9}$ John McClymont, Brief Histories of Parramatta utilities and services, Course notes for Parramatta Evening College, 1998

${ }^{10}$ R Ash and P Heinrichs, 'Parramatta Single Arch Dam - From 1856 and still going strong', First International and Eighth Australian Engineering Heritage Conference, 29 September-2 October 1996, Newcastle, NSW, p 10

${ }^{11} \mathrm{~J}$ Jervis, Parramatta: The cradle of Australia, Parramatta 150th Anniversary Committee, Parramatta NSW, 1938; EJ Statham, 'Parramatta Waterworks', Journal of the Parramatta and District Historical Society, vol 2, 1921

${ }^{12}$ H Chanson and DP James, 'Railway dams in Australia: Six historical structures', Transactions, Newcommen Society, vol 71 no 2, 1999-2000, pp 283-303

${ }^{13}$ R Ash and P Heinrichs, 'Parramatta Single Arch Dam - From 1856 and still going strong', First International and Eighth Australian Engineering Heritage Conference, Newcastle, NSW, 29 September-2 October 1996, fig 3 and p 18

${ }^{14}$ P McKenzie, P Heinrichs, and L Coltheart, 'Cylindrical Arched Dams of New South Wales 18961908: "Work of a courageous Nature"', Fifth National Conference on Engineering Heritage, Perth, 1990

${ }^{15}$ B Cole, L Coltheart and T Moulds, 'Identifying Australia's Heritage Dams', Engineering Heritage Conference Ballarat, Victoria, 15-18 March 1998, pp 89-96

${ }^{16} \mathrm{H}$ Chanson, P James, 'Rapid reservoir sedimentation of four historic thin arch dams in Australia', Journal of Performance of Constructed Facilities, vol 12, no 2, 1998, pp 85-92

${ }^{17}$ Plan of Management Lake Parramatta Reserve, vol 1, Report prepared for Parramatta City Council, 1999, p 20, available at http://www.parracity.nsw.gov.au/home/publications/recreational/lake_parramatta_plan_of_managem ent, viewed 25 February 2009 


\section{Endnotes}

${ }^{18} \mathrm{~J}$ McClymont, Pictorial History: Parramatta and District, Kingsclear Books, Alexandria NSW, 2001, p 37; T Kass, C Liston, J McClymont, Parramatta: A past revealed, Parramatta City Council, Parramatta NSW, 1996, pp 163-4

${ }^{19}$ T Kass, C Liston, J McClymont, Parramatta: A past revealed, Parramatta City Council, Parramatta NSW, 1996, pp 182, 221; John McClymont, Brief histories of Parramatta utilities and services, Course notes for Parramatta Evening College, 1998, p 9

${ }^{20}$ J Jervis, The Cradle City of Australia A history of Parramatta, Council of City of Parramatta, 1978, p 159; J McClymont, Pictorial History: Parramatta and District, Kingsclear Books, Alexandria NSW, 2001, p 68

${ }^{21}$ F Pollon, Parramatta, The Cradle City of Australia: Its History from 1788, Council of City of Parramatta, Parramatta NSW, 1983, p 251

${ }^{22}$ John McClymont, Brief histories of Parramatta utilities and services, Course notes for Parramatta Evening College, 1998 p 6

${ }^{23}$ J Jervis, The Cradle City of Australia A history of Parramatta, Council of City of Parramatta, 1978 p 159; Plan of Management Lake Parramatta Reserve, vol 1, Report prepared for Parramatta City Council, 1999, p 21, available at http://www.parracity.nsw.gov.au/home/publications/recreational/lake_parramatta_plan_of_managem ent, viewed 25 February 2009

${ }^{24}$ J McClymont, Pictorial History: Parramatta and District, Kingsclear Books, Alexandria NSW, 2001, p 116, picture of Lake Parramatta caption

${ }^{25} \mathrm{~J}$ Jervis, Early and recent memoirs of Parramatta, the cradle of Australia, Parramatta 150th Anniversary Committee, 1938, p 77; Lake Parramatta Reserve brochure, Parramatta City Council, undated; Plan of Management Lake Parramatta Reserve, vol 1, Report prepared for Parramatta City Council, 1999, p 92, available at http://www.parracity.nsw.gov.au/home/publications/recreational/lake_parramatta_plan_of_managem ent, viewed 25 February 2009

${ }^{26}$ Plan of Management Lake Parramatta Reserve, vol 1, Report prepared for Parramatta City Council, 1999, p 23, available at

http://www.parracity.nsw.gov.au/home/publications/recreational/lake_parramatta_plan_of_managem ent, viewed 25 February 2009 